\title{
Cost-effectiveness analysis of IDegLira versus basal-bolus insulin for patients with type 2 diabetes in the Slovak health system
}

This article was published in the following Dove Press journal:

ClinicoEconomics and Outcomes Research

\section{Marek Psota' \\ Maria Bucek Psenkova' \\ Natalia Racekova ${ }^{2}$ \\ Antonio Ramirez de \\ Arellano ${ }^{3}$ \\ Tom Vandebrouck ${ }^{4}$ \\ Barnaby Hunt ${ }^{5}$}

'Pharm-In, Ltd., ${ }^{2}$ Novo Nordisk Ltd., Bratislava, Slovakia; ${ }^{3}$ Novo Nordisk Ltd., Madrid, Spain; ${ }^{4}$ Novo Nordisk nv, Brussels, Belgium; ${ }^{5}$ Ossian Health Economics and Communications, Basel, Switzerland
Correspondence: Marek Psota Pharm-In, spol. s.r.o., City Business Center V, Karadžičova 16, 82। 08 Bratislava, Slovakia

Tel +42I 90794 I242

Email marek.psota@pharmin.sk
Aims: To investigate the cost-effectiveness of once-daily insulin degludec/liraglutide (IDegLira) versus basal-bolus therapy in patients with type 2 diabetes not meeting glycemic targets on basal insulin from a healthcare payer perspective in Slovakia.

Methods: Long-term clinical and economic outcomes for patients receiving IDegLira and basal-bolus therapy were estimated using the IMS CORE Diabetes Model based on a published pooled analysis of patient-level data.

Results: IDegLira was associated with an improvement in quality-adjusted life expectancy of 0.29 quality-adjusted life years (QALYs) compared with basal-bolus therapy. The average lifetime cost per patient in the IDegLira arm was EUR 2,449 higher than in the basal-bolus therapy arm. Increased treatment costs with IDegLira were partially offset by cost savings from avoided diabetes-related complications. IDegLira was highly cost-effective versus basal-bolus therapy with an incremental cost-effectiveness ratio of EUR 8,590 per QALY gained, which is well below the cost-effectiveness threshold set by the law in Slovakia.

Conclusion: IDegLira is cost-effective in Slovakia, providing a simple option for intensification of basal insulin therapy without increasing the risk of hypoglycemia or weight gain and with fewer daily injections than a basal-bolus regimen.

Keywords: IDegLira, cost-effective, basal-bolus, insulin intensification, type 2 diabetes

\section{Introduction}

Diabetes mellitus is one of the biggest health challenges facing the world. It significantly reduces life expectancy and quality of life and has a negative impact on socioeconomic opportunities. It is the primary cause of blindness, kidney failure requiring dialysis, and amputations of lower limbs, and is associated with a fourfold increased risk of cardiovascular-related morbidity and mortality. ${ }^{1}$

The International Diabetes Federation estimated that in 2015, approximately 409,000 people in the age group of 20-79 years in Slovakia had diabetes $(9.9 \%$ of the population) and that there were approximately 5,000 diabetes-related deaths. ${ }^{2}$

Diabetes has a substantial economic impact on national health systems, due to an increased use of health services, loss of productivity, and the long-term management of diabetes-related complications. ${ }^{1,2}$ The majority of countries spend between $5 \%$ and $20 \%$ of their total healthcare budget on diabetes, and in Slovakia, the mean diabetes-related expenditure per patient with diabetes was estimated to be around EUR 1,607, in 2015. ${ }^{2}$ 
The clinical goal in the treatment of diabetes is to achieve good glycemic control with minimal hypoglycemia and other adverse effects of treatment, such as weight gain. Intensive glycemic control prevents or delays microvascular complications and reduces cardiovascular and all-cause mortality, 3,4 thereby improving health-related quality of life. ${ }^{5}$ Guidance in Slovakia, in line with international guidance, recommends a target glycated hemoglobin $\mathrm{A}_{1 \mathrm{c}}\left(\mathrm{HbA}_{1 \mathrm{c}}\right.$ ) of less than 7\% (53.0 $\mathrm{mmol} / \mathrm{mol}) .{ }^{6,7}$ In general, for young patients or those with a short duration of diabetes ( $<5-10$ years), a stricter target is recommended $\left(\mathrm{HbA}_{1 \mathrm{c}}<7 \%[53.0 \mathrm{mmol} / \mathrm{mol}]\right.$ or $6.5 \%$ [47.5 $\mathrm{mmol} / \mathrm{mol}])$. Conversely, in elderly multi-morbid patients with long duration of the disease ( $>15-20$ years), the target is often more lenient $\left(\mathrm{HbA}_{1 \mathrm{c}} 7.5 \%\right.$ [53.0 $\left.\mathrm{mmol} / \mathrm{mol}\right]-8 \%$ [63.9 $\mathrm{mmol} / \mathrm{mol}])^{7}$

Type 2 diabetes mellitus (T2DM) accounts for approximately $90 \%$ of all diabetes cases ${ }^{2}$ and is a progressive disease, characterized by insulin resistance and progressive loss of $\beta$-cell function resulting in insulin deficiency. ${ }^{8}$ Therefore, treatment is intensified as the disease progresses. Most patients with T2DM will eventually require insulin to maintain target $\mathrm{HbA}_{1 \mathrm{c}}$ levels, and many patients will need to intensify their insulin regimen over time. ${ }^{6}$ Following are the common strategies for intensification of insulin therapy: to titrate the basal insulin further, add bolus insulin (basalbolus therapy), or switch to premix insulin. ${ }^{6}$ However, these options are associated with an increased risk of hypoglycemia and weight gain, which are among the reasons for clinical inertia (failure to intensify treatment). ${ }^{9}{ }^{10} \mathrm{Complex}$ treatment regimens can also be a barrier for intensification of insulin therapy and good glycemic control. ${ }^{11}$ Recently, international guidelines have included a combination of glucagon-like peptide-1 receptor agonists (GLP-1 RAs) and basal insulin, extending the intensification options available. ${ }^{6}$ With their complementary modes of action, basal insulin and GLP-1 RAs target several of the multiple pathophysiological pathways that contribute to T2DM.

In Slovakia, insulin treatment for T2DM is usually initiated with basal insulin (with or without oral antidiabetic drugs [OADs]). To intensify therapy, bolus insulin in one to three doses (basal-bolus therapy) or a GLP-1 RA is added. ${ }^{7}$ The indication restrictions do not allow the reverse, that is, adding insulin to existing GLP-1 RA treatment, and the use of GLP-1 RAs is currently 5-10 times lower in Slovakia than in other European countries. ${ }^{7}$

Despite clear guidelines, ${ }^{12,13}$ a substantial number of patients with T2DM on insulin therapy have suboptimal glycemic control. ${ }^{10,14,15}$ Data suggest that more than $50 \%$ of the adults with diabetes using basal insulin do not achieve glycemic targets $\left(\mathrm{HbA}_{1 \mathrm{c}}<7 \%[53.0 \mathrm{mmol} / \mathrm{mol}]\right)^{14,15}$ and that patients are not intensified in a timely manner. ${ }^{9}$ In Slovakia, data from the NEFRITI study, ${ }^{16,17}$ which primarily investigated kidney complications in patients with diabetes in Slovakia, suggest that only $29.51 \%$ of the patients with T2DM receiving insulin achieve target $\mathrm{HbA}_{1 \mathrm{c}}$ values $(<7 \%$ [53.0 $\mathrm{mmol} / \mathrm{mol}]$ ) and only $16 \%$ of the patients with T2DM on OADs with insulin achieve target values. ${ }^{18}$

Insulin degludec/liraglutide (IDegLira) is a once-daily combination of a long-acting basal insulin analog (insulin degludec; IDeg) and a GLP-1 RA (liraglutide) administered in a single pen injection device. IDegLira is indicated for the treatment of adults with T2DM to improve glycemic control in combination with oral glucose-lowering medicinal products when these alone or in combination with a GLP-1 RA or basal insulin do not provide adequate glycemic control. ${ }^{19}$ The place in the T2DM treatment pathway for IDegLira is when patients are uncontrolled on basal insulin and require treatment intensification. ${ }^{67}$ IDegLira is currently the only combination of basal insulin and a GLP-1 RA reimbursed in Slovakia. ${ }^{7}$

Two Phase III clinical trials provide evidence for efficacy and safety of IDegLira in patients with T2DM uncontrolled on basal insulin. DUAL ${ }^{\mathrm{TM}}$ (Dual Action of Liraglutide and Insulin Degludec in Type 2 Diabetes) II (NCT01392573)20 showed that IDegLira was superior to IDeg alone at equivalent insulin doses in terms of lowering $\mathrm{HbA}_{1 \mathrm{c}}$, change in body weight, and rates of confirmed hypoglycemia. ${ }^{20}$ DUAL V (NCT01952145) $)^{21}$ showed that IDegLira was superior to insulin glargine U100 (IGlar U100; Lantus ${ }^{\circledR}$, Sanofi Aventis, Paris, France) in terms of lowering $\mathrm{HbA}_{1 \mathrm{c}}$, change in body weight, and rates of hypoglycemia (the rate of confirmed hypoglycemia was 57\% lower with IDegLira than with IGlar U100). ${ }^{21}$

At the time of analysis, there were no head-to-head clinical trials comparing IDegLira with basal-bolus therapy. However, an indirect comparison (pooled multivariable analysis) ${ }^{22}$ of five clinical trials in patients with T2DM inadequately controlled on basal insulin has been conducted comparing IDegLira with basal-bolus therapy, liraglutide plus basal insulin, and up-titration of IGlar U100. The pooled analysis showed that IDegLira was associated with a significantly greater decrease in $\mathrm{HbA}_{1 \mathrm{c}}$, lower hypoglycemia rates, and significant improvements in body weight compared with basal-bolus therapy (weight loss with IDegLira versus weight gain with basal-bolus therapy). ${ }^{22}$

Decision making based on both clinical and economic evidence is essential as healthcare providers seek to optimize resource use and care for patients with T2DM. Analysis of 
cost-effectiveness helps decision makers determine whether the health benefits associated with adopting the novel treatment are worth the cost, compared with existing therapies. An economic analysis typically estimates the difference in cost between one healthcare intervention and an alternative, divided by the difference in health effects, which is termed an incremental cost-effectiveness ratio (ICER):

$$
\text { ICER }=\frac{\text { Cost }_{\text {IDegLira }}-\text { Cost }_{\text {comparator }}}{\text { Effect }_{\text {IDegLira }}-\text { Effect }_{\text {comparator }}}
$$

A generally accepted effectiveness measure used in cost-effectiveness analyses is the quality-adjusted life year (QALY). A QALY is an overall measure of health as a combination of the duration of life and the health-related quality of life. ${ }^{23}$ In Slovakia, a cost-utility analysis of a new intervention is required by the Ministry of Health when seeking reimbursement. Two cost-effectiveness thresholds are set by the law (Act No. 363/2011 ${ }^{24}$ ) and are connected to reference average monthly salary. A drug is generally considered to be cost-effective when the cost per QALY gained is not higher than 24 times the average monthly salary of the population; however, there is also a possibility for conditional reimbursement if the cost per QALY gained is lower than 35 times the average monthly salary of the population.

Cost-effectiveness analyses of diabetes interventions are commonly performed by estimating the long-term clinical consequences as a function of differences in glycemic control. A lifetime time horizon is recommended in guidance on the computer modeling of diabetes ${ }^{25}$ in order to capture all relevant long-term complications and associated costs and assess their impact on life expectancy and quality-adjusted life expectancy.

The objective of this study was to assess the long-term cost-effectiveness of IDegLira versus basal-bolus therapy, for the treatment of patients with T2DM not meeting glycemic targets on basal insulin from a healthcare payer (insurance company) perspective in Slovakia.

\section{Methods}

The design of the model, including choice of comparator, analytical method, and discounting were set in line with Slovak health technology assessment (HTA) guidelines. ${ }^{26}$ Data used in the modeling analysis, for example, costs, were also specific to Slovakia. The analysis follows the standard methodology as prescribed by the IMS CORE Diabetes Model (Version 8.5) and previously published economic evaluations of IDegLira. ${ }^{27,28}$

\section{Choice of comparator}

The most frequently used intensification treatment for patients with T2DM failing on basal insulin recommended by guidance in Slovakia is basal-bolus therapy. ${ }^{7}$ Therefore, the most relevant comparator for IDegLira was considered to be the addition of thrice-daily insulin aspart ( $3 \times$ IAsp) to IGlar U100 or IDeg (basal-bolus therapy).

\section{Type of economic analysis}

A cost-utility analysis was used to compare IDegLira with basal-bolus therapy in patients with T2DM failing to meet glycemic targets $\left(\mathrm{HbA}_{1 \mathrm{c}}>7 \%\right.$ [53.0 $\left.\left.\mathrm{mmol} / \mathrm{mol}\right]\right)$ on basal insulin. Cost-effectiveness was expressed as an ICER (cost per QALY gained).$^{23}$ The ICER threshold considered to represent acceptable value for money in Slovakia at the time of this analysis was EUR 19,776 per QALY gained (Act No. 363/201124).

\section{Overview of the cost-effectiveness model}

Long-term clinical and economic outcomes were estimated using the IMS CORE Diabetes Model, an internet-based, interactive model developed to project long-term health outcomes, costs, and cost-effectiveness of interventions for type 1 diabetes mellitus and T2DM. ${ }^{29,30}$ The model allows extrapolation of results from short-term trials to long-term outcomes. It accounts for diabetes therapy, OADs, screening and treatment strategies for micro- and macrovascular complications, treatment strategies for end-stage complications, and multifactorial interventions. The following long-term outcomes are evaluated: life expectancy, quality-adjusted life expectancy, cumulative incidence of diabetes-related complications, time to onset of diabetes-related complications, and direct medical costs.

The IMS CORE Diabetes Model is based on a series of sub-models that simulate important complications of diabetes and takes data from a number of different sources to perform patient-level simulations (Figure 1). Baseline cohort characteristics are used to define a simulated patient and treatment effects based on the trial data are applied. Other diabetes management strategies are also included, since these affect the risk of complications. The simulated patient then enters the model, in which clinical events are projected over the patient's lifetime. Based on these clinical events and their impact on costs and quality of life, health economic outcomes are projected.

\section{Time horizon and treatment duration}

The base case analysis used a lifetime (50 year) time horizon as this allowed all relevant long-term diabetes-related 


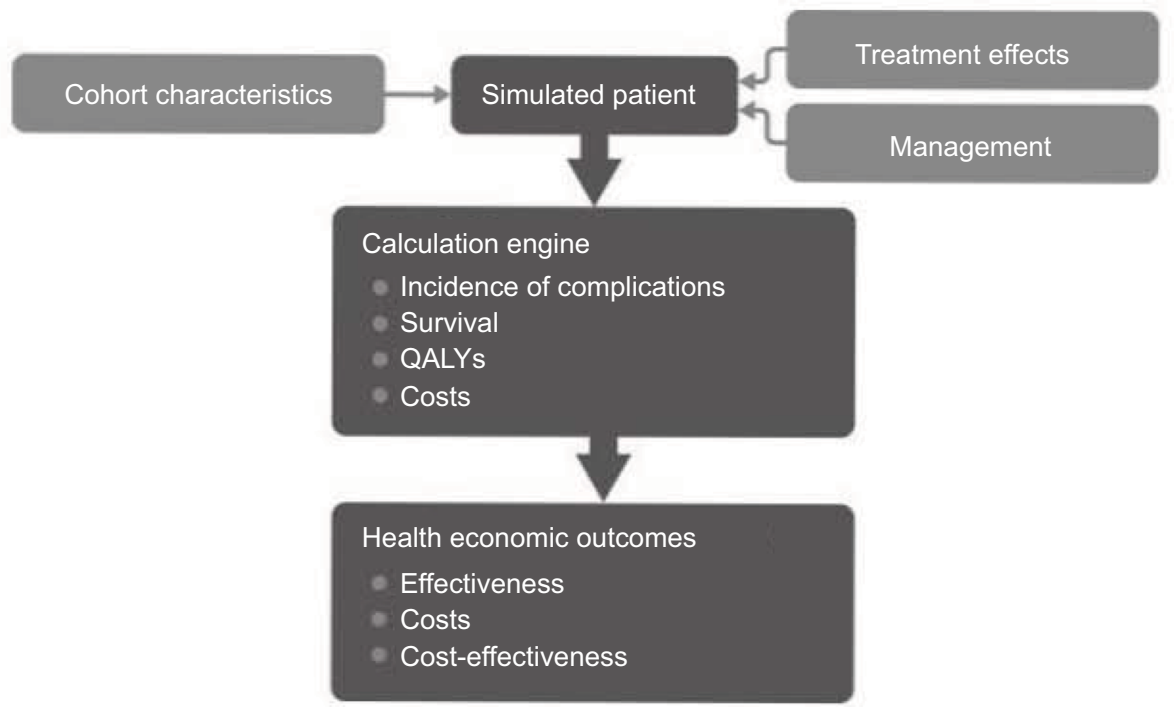

Figure I Performing simulations with the IMS CORE Diabetes Model. Abbreviation: QALY, quality-adjusted life year.

complications and associated costs to be captured. The model takes into account mortality as a result of diabetesrelated complications and background mortality based on Slovakia-specific life tables. ${ }^{31}$ Therefore, whilst a 50 -year time horizon was used, patients were not assumed to live for 50 years, and all patients had died within the 50-year time horizon of the analysis.

Patients receiving IDegLira were assumed to undergo the same treatment for the first 5 years of the analysis, after which treatment was intensified to basal-bolus therapy (IGlar $\mathrm{U} 100 \mathrm{OD}+3 \times \mathrm{IAsp})$. This assumption recognizes that intensification to basal-bolus therapy is likely to be required for patients to maintain glycemic control over the long term. In the basal-bolus therapy arm, patients were assumed to remain on this therapy for the duration of their lifetime. The impact on long-term outcomes of the $\mathrm{HbA}_{1 \mathrm{c}}$ benefit with IDegLira in the first 5 years of treatment is captured by the model.

\section{Discounting}

Clinical and cost outcomes were discounted at $5 \%$ per annum in line with guidelines for the economic evaluation of healthcare interventions in Slovakia. ${ }^{26,32}$

\section{Clinical data}

A simulated cohort of patients was defined, with baseline risk factors derived from the baseline characteristics of patients randomly allocated to receive IDegLira in the DUAL II study (Table S1). ${ }^{20}$ The proportion of smokers was based on the trial data, but the number of cigarettes smoked per day was assumed to be the same as the general Slovakian population. ${ }^{33}$
Similarly, mean weekly alcohol consumption was taken from Slovak-specific data for the general population. ${ }^{34}$

Treatment effects for IDegLira and basal-bolus therapy applied in the first year of the analysis (Table 1) were based on data from the pooled analysis. ${ }^{22}$ Data were taken from the IDegLira arm $(n=199)$ and the basal-bolus arm $(n=210)$ of the supplementary pooled analysis. The basal-bolus therapy arm in the supplementary analysis included patients receiving IGlar U100 + 3× IAsp or IDeg $+3 \times$ IAsp. After the first year of the modeling analysis, systolic blood pressure and serum lipids were assumed to follow the natural progression algorithms built into the IMS CORE Diabetes Model, based on the UK Prospective Diabetes Study (UKPDS) or Framingham data (as described by Palmer et $\mathrm{al}^{30}$ ). Benefits in terms of $\mathrm{HbA}_{1 \mathrm{c}}$ and body mass index (BMI) were assumed to persist for the 5-year period when patients received IDegLira and were abolished on treatment switching. Following treatment intensification, hypoglycemia rates in the basal-bolus arm were also applied to the IDegLira arm.

\section{Costs and resource use}

Costs were estimated from a Slovak healthcare payer perspective. Direct costs included pharmacy costs, costs associated with treatment of diabetes-related complications, and concomitant patient management costs. All costs were expressed in 2015 EUR.

Treatment costs were calculated based on the adjusted doses in the pooled analysis from which clinical data on the treatment effects were also taken. ${ }^{22}$ All patients were assumed to be receiving metformin in addition to the study 
Table I Treatment effects applied in patients previously uncontrolled on basal insulin

\begin{tabular}{|c|c|c|}
\hline Parameter & IDegLira & Basal-bolus therapy \\
\hline $\mathrm{HbA}_{\mathrm{Ic}}(\%)$ & $-1.66(0.96)$ & $-1.33(0.96)^{*}$ \\
\hline $\mathrm{HbA}_{\mathrm{lc}}(\mathrm{mmol} / \mathrm{mol})$ & $-18(-12)$ & $-14(I I)$ \\
\hline $\mathrm{SBP}(\mathrm{mmHg})$ & $-6.86(13.20)$ & $-0.93(13.20)^{*}$ \\
\hline Total cholesterol (mg/dL) & $-10.13(30.28)$ & $+1.50(30.28)^{*}$ \\
\hline HDL cholesterol (mg/dL) & $+0.52(6.79)$ & $+0.79(6.79)$ \\
\hline LDL cholesterol (mg/dL) & $-6.85(23.83)$ & $+0.08(23.83)^{*}$ \\
\hline Triglycerides (mg/dL) & $-25.74(103.7 I)$ & $+3.82(103.7 I)^{*}$ \\
\hline $\mathrm{BMI}\left(\mathrm{kg} / \mathrm{m}^{2}\right)$ & $-1.04(1.34)$ & $+1.38(1.34)^{*}$ \\
\hline Severe hypoglycemia event rate (events/l00 PYE) [95\% Cl] & 0.84 & 2.85 \\
\hline Non-severe hypoglycemia event rate (events/I00 PYE) $[95 \% \mathrm{Cl}]$ & 125.05 & $794.63 *$ \\
\hline Actual daily basal insulin $(U)$ at EOT & $37.27(30.22)$ & $68.22(30.22)^{*}$ \\
\hline Actual daily bolus insulin $(\mathrm{U})$ at EOT & - & $57.88(\mathrm{NR})$ \\
\hline
\end{tabular}

Notes: Data presented as mean (standard deviation). Extended pooled analysis. ${ }^{22}$ \#Basal bolus therapy was IGlar $+3 \times$ IAsp or IDeg $+3 \times$ IAsp. *Statistically significant difference between treatment arms. Reproduced from Hunt B, Glah D, van der Vliet M. Modeling the Long-Term Cost-Effectiveness of IDegLira in Patients with Type 2 Diabetes Who are Failing To Meet Glycemic Targets on Basal Insulin Alone in The Netherlands. Diabetes Ther. 2017;8(4):753-765. ${ }^{27}$

Abbreviations: BMI, body mass index; Cl, confidence interval; EOT, end-of-trial; HbAlc, glycated hemoglobin $\mathrm{A}_{\text {Ic }}$; HDL, high-density lipoprotein; IAsp, insulin aspart; IDeg, insulin degludec; IDegLira; insulin degludec/liraglutide; IGlar, insulin glargine; LDL, low-density lipoprotein; NR, not reported; PYE, patient years of exposure; SBP, systolic blood pressure; SD, standard deviation.

medications. Following treatment intensification to basalbolus therapy, treatment costs were the same in both arms (matched to IGlar U100 + 3× IAsp). Costs of self-monitoring of blood glucose (SMBG) testing and needles for injection of insulin were not included in the analysis as the same number of test strips and needles were reimbursed regardless of the treatment used as an intensification strategy, and therefore, there was no difference in cost between the treatment arms. This is likely to be a conservative approach as resource use associated with these aspects of care is likely to be higher with basal-bolus insulin than with IDegLira. All costs of medicines were taken from the list of reimbursed drugs (November 2015) published by the Ministry of Health of the Slovak Republic. ${ }^{35}$ Only reimbursed costs were taken into consideration (co-pays were not included). The total annual per-patient cost for IDegLira was EUR 1,836.21 (IDegLira daily cost EUR 4.92; metformin daily cost EUR 0.106) versus EUR 1,181.37 for basal-bolus therapy (IGlar U100 daily cost EUR 1.92; IAsp daily cost EUR 1.20; metformin daily cost EUR 0.106). Whilst pooled treatment effects (IGlar + $3 \times$ IAsp and IDeg $+3 \times$ IAsp) were used to inform changes in physiological parameters, conservatively only unit costs of IGlar U100 were used to calculate annual treatment costs (as IGlar U100 is associated with a lower cost).

The analysis captured the proportion of patients receiving concomitant medications, screening for renal disease, retinopathy and diabetic foot complications, and post-complication management such as intensive insulin treatment after myocardial infarction. Resource use relating to patient management was assumed to be the same as the general population with T2DM in Slovakia in both treatment arms. Costs of laboratory tests and appointments with healthcare professionals were taken from a published source. ${ }^{36}$ Tables S2 and $\mathrm{S} 3$ present the resource use and costs.

The cost of diabetes-related complications in the year of the event and the annual follow-up costs were identified through a literature review (Table S4). ${ }^{36}$

\section{Estimation of quality-adjusted life expectancy}

As diabetes progresses, patients develop complications that influence their overall health-related quality of life, and therefore, both mortality and morbidity were evaluated to address the disutility impact associated with each of the complications modeled. Utilities were taken from published sources. ${ }^{30,37-41}$

\section{Sensitivity analyses}

Sensitivity analyses were performed to assess the robustness of the base case findings. These analyses varied model assumptions, either in line with Slovak methodology guidance requirements ${ }^{26}$ or replaced a base case parameter with an alternative published data point.

\section{Time horizon}

The time horizon was increased by $30 \%$ (to 65 years) and decreased by $30 \%$ (to 35 years). At a time horizon of 35 years, not all modeled patients had died, and therefore, this analysis did not capture all complications and costs. Conversely, increasing the time horizon beyond 50 years had no effect as all patients had died.

\section{Discount rate}

Analyses were performed with discount rates increased by $30 \%$ (to $6.5 \%$ ) and decreased by $30 \%$ (to $3.5 \%$ ). 


\section{Key drivers of clinical benefit}

Ten simulations were run to assess the key drivers of clinical benefit associated with IDegLira versus basal-bolus therapy. The difference in $\mathrm{HbA}_{1 \mathrm{c}}$, systolic blood pressure, serum lipids, BMI, and hypoglycemia between the IDegLira arm and the basal-bolus therapy arm was increased or decreased by $30 \%$. This allowed the contribution of individual clinical effects to long-term health economic outcomes to be assessed.

\section{Treatment switching patterns}

Simulations were performed with the year of treatment switch to basal-bolus therapy in the IDegLira arm brought forward to the end of year 3 and pushed back to the end of year 7 , and no treatment switching.

\section{Cost of complications}

The cost of treating complications was increased by $30 \%$ and decreased by $30 \%$.

\section{Hypoglycemia disutilities}

The disutilities for severe and non-severe hypoglycemic events were varied by increasing and decreasing the values applied by $30 \%$.

\section{Update to the IMS CORE Diabetes Model}

In February 2014, an update to the IMS CORE Diabetes Model incorporating data from UKPDS 82 was released, and an analysis using this version of the model has been run.

\section{Pooled analysis with narrow basal-bolus arm}

The base case comparison used data from an extended pooled statistical analysis in which patients receiving both IGlar U100 + 3× IAsp and IDeg + 3× IAsp were included in the basal-bolus arm. In addition, a pooled analysis was conducted, including only patients receiving IGlar U100 + $3 \times$ IAsp. $^{22}$ These data were applied in a sensitivity analysis.

\section{Probabilistic sensitivity analysis}

Probabilistic sensitivity analysis (PSA) was performed using the predefined function in the IMS CORE Diabetes Model.
Cohort characteristics, treatment effects, complication costs, and utilities were sampled from distributions and the simulation was run using a second-order Monte Carlo approach. Cohorts of 1,000 patients were run through the model 1,000 times for the PSA, as results were not subject to random statistical variation with these settings.

\section{Results}

\section{Base case analysis}

Projections of long-term clinical outcomes indicated that IDegLira was associated with an improvement in qualityadjusted life expectancy of 0.29 QALYs versus basal-bolus therapy (Table 2). Clinical benefits resulted from a reduced incidence of diabetes-related complications in the IDegLira arm over the 50-year time horizon of the analysis. In addition to reducing the projected cumulative incidence of complications, IDegLira was associated with a delayed mean time to onset of diabetes-related complications.

Evaluation of the direct medical costs over patients' lifetimes suggested that the mean cost per patient in the IDegLira arm was EUR 2,449 higher than in the basalbolus therapy arm (Table 2). IDegLira was associated with increased treatment costs (driven by the acquisition costs over the first 5 years of the analysis), but this was partially offset by cost savings as a result of avoided diabetes-related complications.

Estimation of long-term clinical outcomes indicated that both life expectancy and quality-adjusted life expectancy were improved with IDegLira treatment compared with basal-bolus therapy. This was achieved at an increased cost from a healthcare payer perspective. The ICER based on direct costs and quality-adjusted life expectancy was EUR 8,590 per QALY gained (Table 2).

\section{One-way sensitivity analyses}

Sensitivity analyses showed that the base case results were robust to changes in the input parameters, with the majority of analyses having only a small impact on the ICER. Results of the sensitivity analyses are presented as a tornado diagram (Figure 2) and are tabulated in Table S5.

Table 2 Base case analysis

\begin{tabular}{llll}
\hline & IDegLira & Basal-bolus therapy & Difference \\
\hline Discounted life expectancy (years) & $10.67(0.14)$ & $10.58(0.14)$ & 0.10 \\
Discounted QALYs & $6.93(0.09)$ & $6.65(0.09)$ & 0.29 \\
Discounted direct costs (EUR) & $25,054(591)$ & $22,605(582)$ & 2,449 \\
ICER (life expectancy) & EUR 24,687 per life year gained & & \\
ICER (quality-adjusted life expectancy) & EUR 8,590 per QALY gained & & \\
\hline
\end{tabular}

Notes: Data presented as mean (standard deviation). EUR, 2015 Euros.

Abbreviations: ICER, incremental cost-effectiveness ratio; IDegLira; insulin degludec/liraglutide; QALY, quality-adjusted life year; SD, standard deviation. 


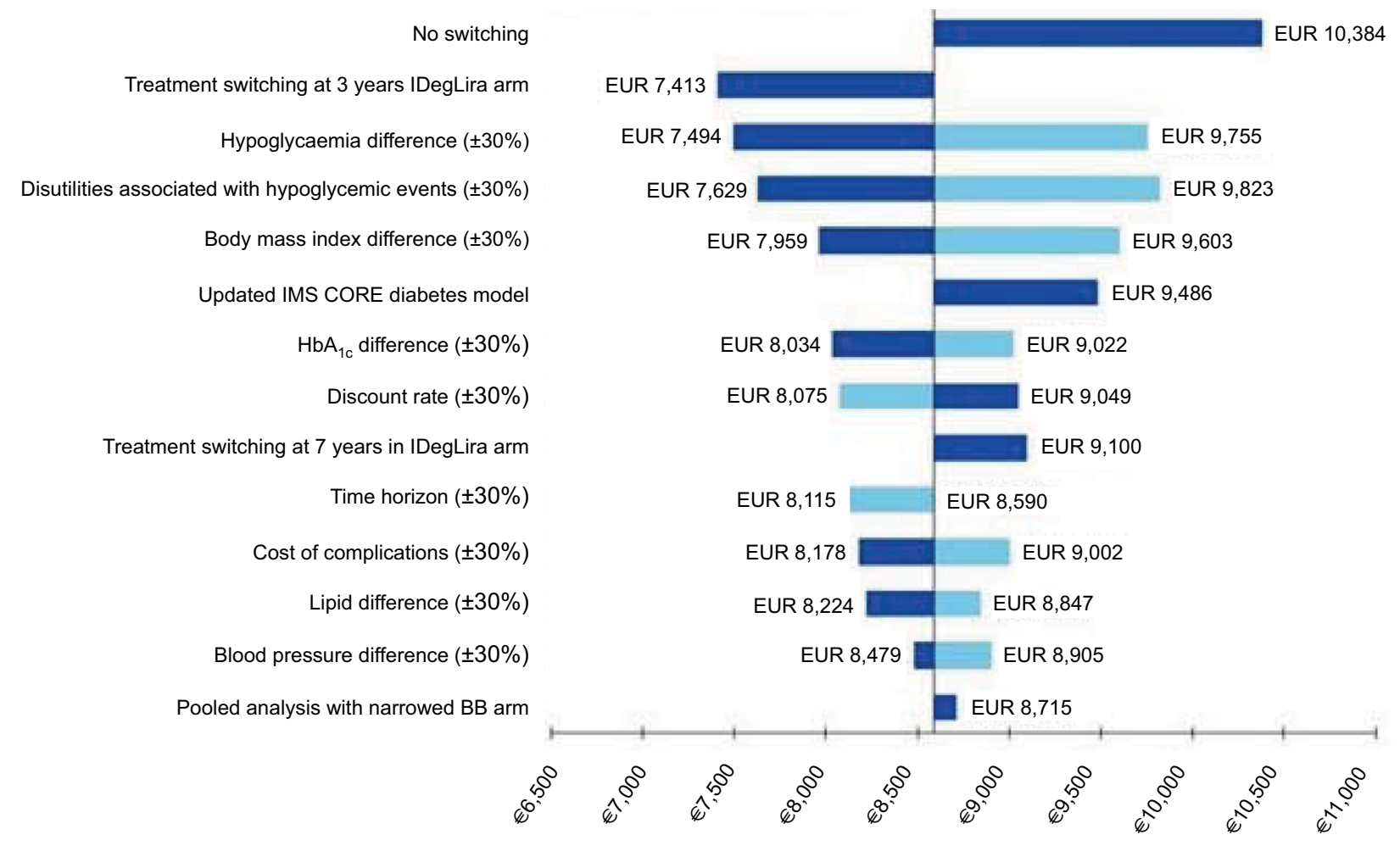

Figure 2 Tornado diagram showing sensitivity analysis results.

Notes: The solid vertical line represents the base case ICER (EUR 8,590 per QALY gained). Dark blue bars indicate an increase in the given parameter and light blue bars a decrease. EUR, 2015 Euros.

Abbreviations: BB, basal-bolus; HbAIc, glycated hemoglobin AIc; ICER, incremental cost-effectiveness ratio; IDegLira; insulin degludec/liraglutide; QALY, quality-adjusted life year.

Increasing or decreasing the differences in treatment effects identified that the key drivers of improved clinical outcomes were reduced rates of hypoglycemia and the reduction in BMI. However, these analyses also identified that other treatment effects were important, showing the multifactorial benefits of IDegLira therapy. IDegLira was associated with improved clinical outcomes even when treatment differences were reduced by $30 \%$.

Changing the assumptions around treatment switching had an impact on the calculated health economic outcomes. Maintaining patients on IDegLira for longer time increased the incremental clinical benefit and the incremental cost associated with IDegLira. Assuming that patients remained on IDegLira for the duration of their lifetimes led to a quality-adjusted life expectancy benefit of 0.65 QALYs at an increased cost of EUR 6,724. This resulted in an ICER of EUR 10,384 per QALY gained.

Increasing the cost of treatment of diabetes-related complications resulted in reduced incremental costs with IDegLira, whilst IDegLira was associated with increased incremental costs when the cost of complications was reduced. Reducing the cost of treating diabetes-related complications by $30 \%$ resulted in an ICER of EUR 9,002 per QALY gained.
Increasing or decreasing the disutilities associated with hypoglycemic events had a large impact on the qualityadjusted life expectancy benefit with IDegLira. This reflects the importance of reductions in hypoglycemic events with IDegLira versus basal-bolus therapy. When the disutilities associated with hypoglycemic events were decreased by $30 \%$, IDegLira was associated with an ICER of EUR 9,823 per QALY gained.

\section{Probabilistic sensitivity analysis}

The incremental cost-effectiveness scatterplot presents the incremental costs versus incremental effectiveness (QALYs gained) for IDegLira versus basal-bolus therapy (Figure 3A), and shows 1,000 mean values, each from a cohort of 1,000 patients run through the model with sampling from distributions around model input parameters. The majority (98.2\%) of points fell in the upper right quadrant with both increased effectiveness (ie, incremental quality-adjusted life expectancy) and increased total costs for IDegLira compared with basal-bolus therapy.

The data from the scatterplot were used to generate a cost-effectiveness acceptability curve (Figure 3B). Based on this analysis, assuming a willingness-to-pay threshold 
A

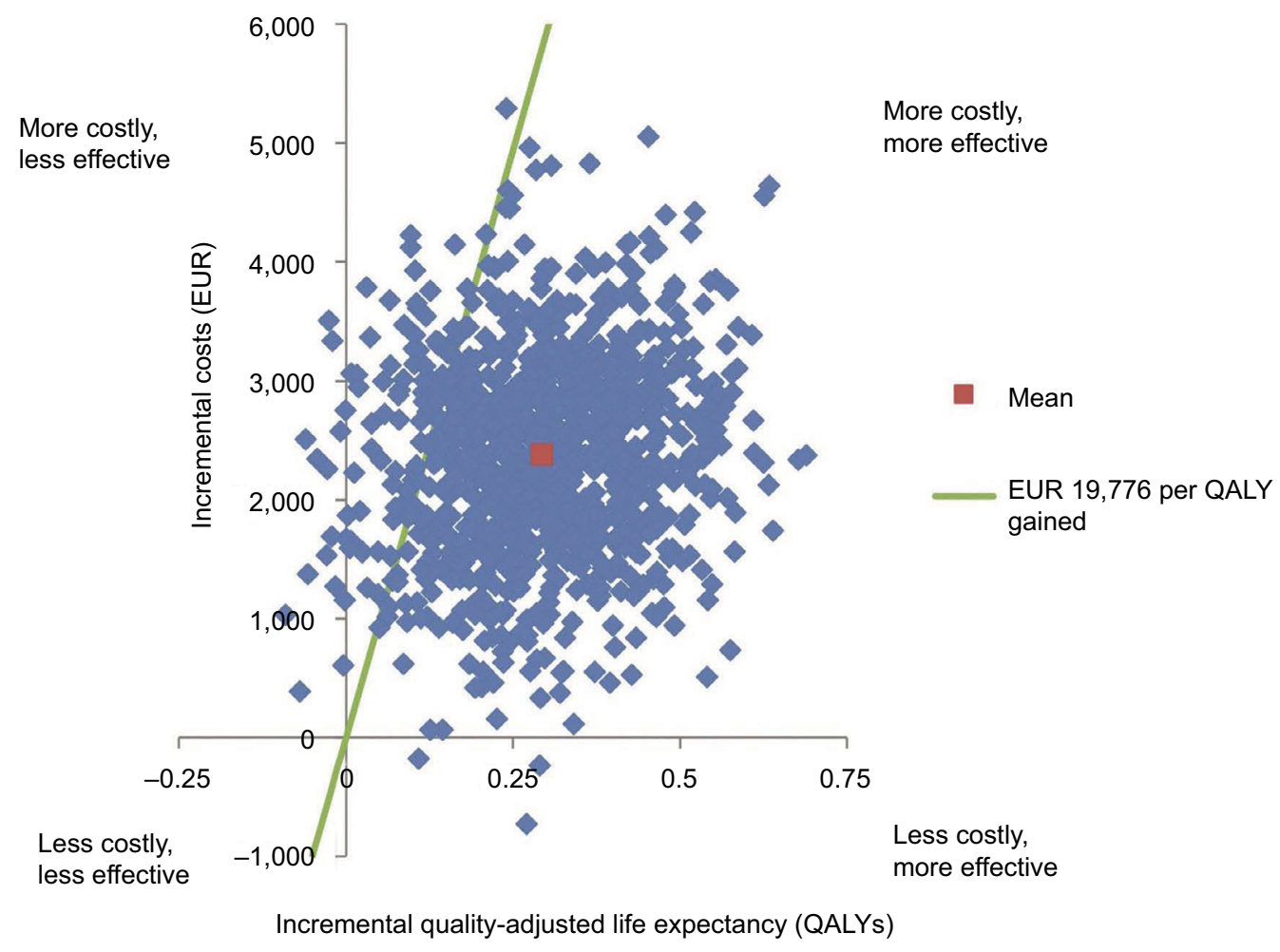

B

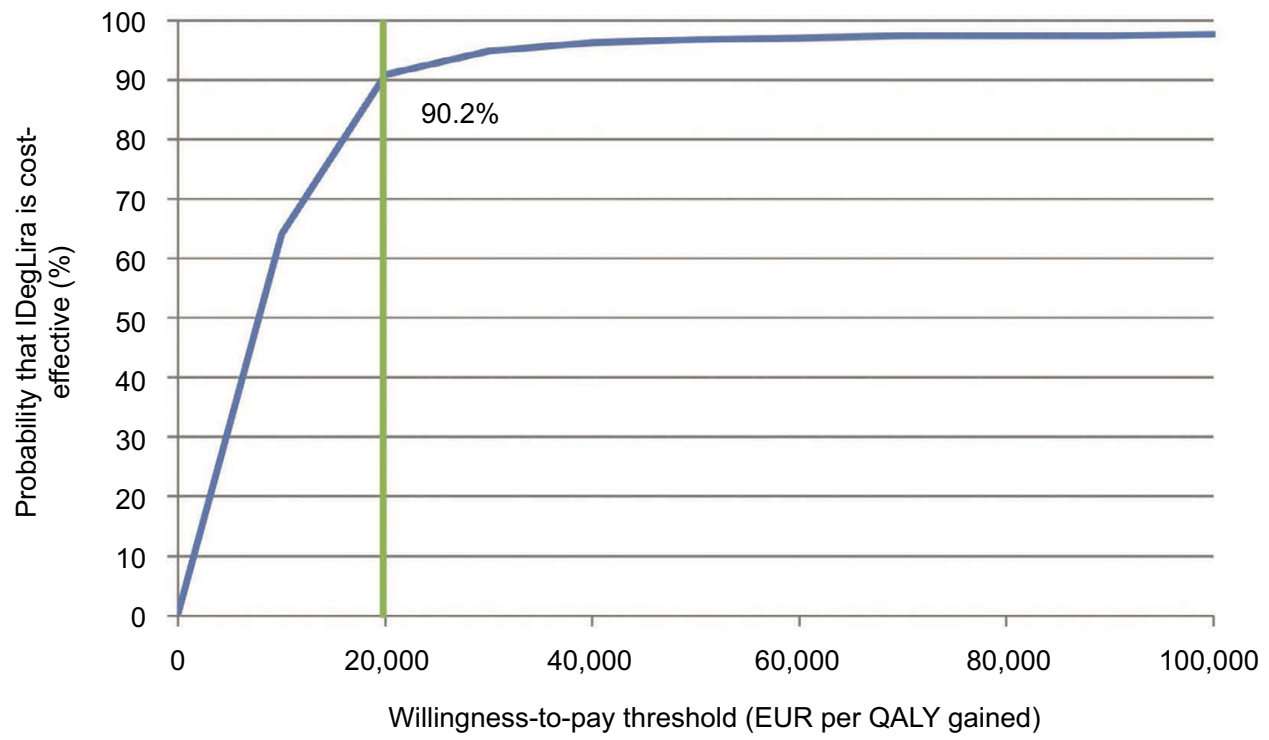

Figure 3 Probabilistic sensitivity analysis.

Notes: Cost-effectiveness scatterplot (A). Cost-effectiveness acceptability curve (B). EUR, 2015 Euros.

Abbreviations: IDegLira; insulin degludec/liraglutide; QALY, quality-adjusted life year.

of EUR 19,776 per QALY gained, the modeling analysis indicated that there was a $90.2 \%$ probability that IDegLira was considered cost-effective versus basal-bolus therapy.

\section{Discussion}

This long-term economic evaluation found that IDegLira was associated with an ICER of EUR 8,590 per QALY gained versus basal-bolus therapy. This falls below the legally set 
willingness-to-pay threshold of EUR 19,776 per QALY gained, and therefore, IDegLira is likely to be considered cost-effective for patients with T2DM failing to achieve glycemic control on basal insulin in Slovakia. IDegLira was approved for reimbursement in Slovakia by the Ministry of Health in June $2016,{ }^{42}$ and this analysis formed the basis for the positive reimbursement decision.

IDegLira was associated with improved clinical outcomes compared with basal-bolus therapy. Sensitivity analyses identified that the key drivers of superior clinical outcomes with IDegLira were reductions in BMI and lower rates of severe and non-severe hypoglycemia. However, changes in $\mathrm{HbA}_{1 \mathrm{c}}$, systolic blood pressure, and serum lipids were also important, showing the multifactorial benefits of treatment with IDegLira. IDegLira was associated with increased direct costs over patient lifetimes from a healthcare payer perspective. This was driven by the higher annual cost of IDegLira versus basal-bolus therapy over the first 5 years of the analysis. However, this was partially offset by cost savings due to avoided treatment of diabetes-related complications as a result of improved treatment.

Extensive sensitivity analyses found that the conclusions were robust to changes in input parameters and modeling assumptions. Compared to basal-bolus therapy, IDegLira was cost-effective in all the investigated scenarios, with the majority of analyses having little or no impact on the ICER. In all scenarios, the ICER was well below the legally set willingness-to-pay threshold of EUR 19,776 per QALY gained. PSA showed a very high probability $(90.2 \%)$ that IDegLira would be cost-effective versus basal-bolus therapy at this willingness-to-pay threshold.

The analysis used relatively short-term clinical trial data to make long-term projections, which is a potential limitation of the study. Making long-term projections from short-term data is common to a number of health economic analyses and is one of the best available options to inform decision making in the absence of long-term clinical trial data. Whilst there is always an element of clinical uncertainty around the accuracy of this approach, this analysis sought to minimize this uncertainty by using a model of diabetes that has been extensively published and validated against real-life data both on first publication and recently following a series of model updates..$^{29,43}$ Projecting outcomes over patient lifetimes is recommended in guidelines for economic evaluation of interventions for patients with diabetes mellitus. ${ }^{25}$

As part of our analysis, a simulated cohort of patients was defined, with baseline risk factors derived from the baseline characteristics of patients randomly allocated to receive
IDegLira in the DUAL II study. ${ }^{20}$ Data from the DUAL II study contributed to the pooled analysis ${ }^{22}$ which was used to provide treatment effects for IDegLira and basal-bolus therapy in the first year of this economic analysis. Data from the DUAL V study, ${ }^{21}$ which investigated the efficacy of IDegLira versus up-titration of IGlar U100 in patients with T2DM uncontrolled on IGlar U100 at trial entry, ${ }^{21}$ were not available at the time the pooled analysis was conducted.

In Slovakia, treatment of patients with T2DM failing to achieve glycemic control on basal insulin therapy is most commonly intensified through the gradual addition of 1-3 doses of fast-acting prandial insulin to basal insulin. However, basal-bolus insulin therapy is associated with a higher risk of hypoglycemia and weight gain. IDegLira represents an alternative to basal-bolus insulin therapy, and takes advantage of the complementary mechanisms of action of the two constituent agents to offer effective glycemic control without an elevated risk of hypoglycemia or weight gain. At the time of analysis, no head-to-head trials comparing IDegLira with basal-bolus therapy have been published (although studies are in progress).

Indirect analyses, using robust methodologies, can provide useful information for medical decision making and are increasingly being accepted for HTA globally ${ }^{39}$ The pooled analysis uses individual patient-level data, which may be considered superior to aggregated study-level data, and the methodology is recognized by the European Network for Health Technology Assessment (EUnetHTA) guidelines on how to conduct indirect analyses..$^{44}$ Equivalent methodology has been used previously to assess outcomes in patients with T2DM. ${ }^{45}$ In order to increase the number of patients in the basal-bolus therapy arm (and therefore the robustness of the analysis), the pooled analysis used to inform this costeffectiveness analysis included patients previously receiving basal insulin randomly allocated to receive IGlar U100 + 3x IAsp and IDeg $+3 \times$ IAsp..$^{22}$ Whilst pooled treatment effects were used to inform changes in physiological parameters, unit costs of IGlar U100 were used to calculate annual treatment costs (rather than weighting the costs by the proportion receiving IGlar U100 or IDeg in the trial). This is likely to be a conservative approach as IDeg is associated with lower rates of hypoglycemia compared with IGlar U100 ${ }^{46}$ but IGlar U100 is associated with a lower cost than IDeg.

Another potential limitation of the study is that the costs of diabetes-related complications used in the analysis were derived from a single publication identified through a literature review. ${ }^{36}$ The publication is not available in English and is a qualitative research study, where resource use is 
estimated by key opinion leaders (Delphi panel). However, the method is accepted by the Slovak Ministry of Health in the absence of other current data sources. Furthermore, the effect of varying the cost of diabetes-related complications $( \pm 30 \%)$ was tested in sensitivity analysis, and had little impact on the ICER.

IDegLira is an effective treatment option for patients with T2DM uncontrolled on basal insulin, offering a reduced risk of hypoglycemia and weight gain versus basal-bolus insulin therapy, ${ }^{21,22}$ both of which are common barriers to treatment intensification. ${ }^{21}$ IDegLira may also offer advantages from an adherence perspective as it is associated with less nausea than typically observed with GLP-1 RAs, a likely result of the gradual increase in the dose of the liraglutide component of IDegLira during dose titration. ${ }^{47}$ Furthermore, the oncedaily dosing of IDegLira means that patients have a simple treatment option, with up to three fewer daily injections than basal-bolus insulin regimens. The combination of IDeg and liraglutide in a single pen device means that patients will only need to perform a single dose adjustment, and consumable costs (eg, needles and SMBG testing) will be lower than that with basal-bolus insulin therapy.

In conclusion, obtaining value for money is an essential component in the application of new health technologies into routine clinical practice. Our results suggest that IDegLira is cost-effective in Slovakia, providing a simple basal insulin intensification option without increased risk of hypoglycemia or weight gain, and without an increased number of daily injections compared with basal-bolus insulin therapy.

\section{Acknowledgment}

This study was funded by Novo Nordisk.

\section{Author contributions}

All authors contributed toward data analysis, drafting and critically revising the paper and agree to be accountable for all aspects of the work.

\section{Disclosure}

N Racekova, A Ramirez de Arellano, and T Vandebrouck are employees of Novo Nordisk. B Hunt is an employee of Ossian Health Economics and Communications. Ossian received consulting fees from Novo Nordisk to support the analysis. M Bucek Psenkova is the general manager of Pharm-In and M Psota is an employee of Pharm-In. Pharm-In received consulting fees from Novo Nordisk to support the analysis. The authors acknowledge the assistance of DRG Abacus (sponsored by Novo Nordisk) for medical writing and editorial support. The authors report no other conflicts of interest in this work.

\section{References}

1. Slovak Diabetes Society. National diabetes program (NDP) Slovakia. Available from: http://www.diaslovakia.sk/contentData/0225/ National\%20Diabetes\%20Program\%20(NDP)\%20Slovakia.pdf. Accessed October 5, 2017.

2. International Diabetes Federation. IDF Diabetes Atlas 7th edition. 2015. Available from: http://www.idf.org/idf-diabetes-atlas-seventh-edition. Accessed October 5, 2017.

3. Stratton IM, Adler AI, Neil HA, et al. Association of glycaemia with macrovascular and microvascular complications of type 2 diabetes (UKPDS 35): prospective observational study. BMJ. 2000;321(7258):405-412.

4. The Diabetes Control and Complications Trial Research Group. The effect of intensive treatment of diabetes on the development and progression of long-term complications in insulin-dependent diabetes mellitus. N Engl J Med. 1993;329(14):977-986.

5. U.K. Prospective Diabetes Study Group. Quality of life in type 2 diabetic patients is affected by complications but not by intensive policies to improve blood glucose or blood pressure control (UKPDS 37). Diabetes Care. 1999;22(7):1125-1136.

6. Inzucchi SE, Bergenstal RM, Buse JB, et al. Management of hyperglycemia in type 2 diabetes, 2015: a patient-centered approach: update to a position statement of the American Diabetes Association and the European Association for the study of diabetes. Diabetes Care. 2015;38(1):140-149.

7. Martinka E, Uličiansky V, Mokáň M, et al. Konsenzuálny terapeutický algoritmus pre diabetes mellitus 2. typu. [Consensual treatment algorithm for type 2 diabetes]. Intern Med. 2016;16(7-8):301-310. Slovak.

8. Bagust A, Beale S. Deteriorating beta-cell function in type 2 diabetes: a long-term model. QJM. 2003;96(4):281-288.

9. Khunti K, Nikolajsen A, Thorsted BL, Andersen M, Davies MJ, Paul SK. Clinical inertia with regard to intensifying therapy in people with type 2 diabetes treated with basal insulin. Diabetes Obes Metab. 2016;18(4):401-409.

10. Phan T, Boutmy E, Coulombel N. A cross-sectional study on insulin treatments and glycemic control in type 2 diabetes in France, Italy, Germany, UK and Spain. Value Health. 2015;18(7):A599.

11. Peyrot M, Barnett AH, Meneghini LF, Schumm-Draeger PM. Insulin adherence behaviours and barriers in the multinational Global Attitudes of Patients and Physicians in Insulin Therapy study. Diabet Med. 2012;29(5):682-689.

12. American Diabetes Association. Standards of medical care in diabetes2014. Diabetes Care. 2014;37 Suppl 1:S14-S80.

13. International Diabetes Federation (IDF). Clinical Guidelines Task Force. Global guideline for type 2 diabetes. 2012. Available from: https://www. idf.org/e-library/guidelines/79-global-guideline-for-type-2-diabetes. Accessed October 5, 2017.

14. Dale J, Martin S, Gadsby R. Insulin initiation in primary care for patients with type 2 diabetes: 3-year follow-up study. Prim Care Diabetes. 2010; $4(2): 85-89$.

15. Giugliano D, Maiorino MI, Bellastella G, Chiodini P, Ceriello A, Esposito K. Efficacy of insulin analogs in achieving the hemoglobin A1c target of $<7 \%$ in type 2 diabetes: meta-analysis of randomized controlled trials. Diabetes Care. 2011;34(2):510-517.

16. Martinka E, Pontuch P. The prevalence of diabetic nephropathy in patients with type 2 diabetes mellitus in Slovakia: the NEFRITI study. Poster presented at: the 51st Annual Meeting of the European Association for the Study of Diabetes; September 14-18, 2015; Stockholm.

17. Martinka E, Pont'uch $\mathrm{P}$, Mišániková $\mathrm{M}$, et al. Incidence of diabetic nephropathy in a population of patients with diabetes mellitus in Slovakia: results of the NEFRITI investigation. Forum Diab. 2015;4(3):198-207.

18. Martinka E. Stav kompenzácie pacientov s DM2 na Slovensku. Kompendium Mediciny. 2015;7:33-34. 
19. European Medicines Agency. Xultophy ${ }^{\circledR}$ (IDegLira) summary of product characteristics. Available from: https://www.google.co.uk/url?sa=t\& $\mathrm{rct}=\mathrm{j} \& \mathrm{q}=\&$ esrc $=\mathrm{s} \&$ source $=$ web $\& \mathrm{~cd}=2 \& \mathrm{cad}=\mathrm{rja} \&$ uact $=8 \& \mathrm{ved}=0 \mathrm{ah}$ UKEwjyhrrXkdnWAhXFQCYKHVYjB6UQFggtMAE\&url=http $\% 3$ A $\% 2$ F\%2Fwww.ema.europa.eu $\% 2$ Fdocs $\% 2 F e n \_G B \% 2 F d o c u m e n t$ library\%2FEPAR_-_Product_Information $\% 2$ Fhuman $\% 2$ F $002647 \% 2$ FWC500177657.pdf\&usg=AOvVaw2M6zExdSOxolET_WebKOAv. Accessed October 5, 2017.

20. Buse JB, Vilsbøll T, Thurman J, et al; NN9068-3912 (DUAL-II) Trial Investigators. Contribution of liraglutide in the fixed-ratio combination of insulin degludec and liraglutide (IDegLira). Diabetes Care. 2014;37(11):2926-2933.

21. Lingvay I, Pérez Manghi F, García-Hernández P, et al; DUAL V Investigators. Effect of insulin glargine up-titration vs insulin degludec/ liraglutide on glycated hemoglobin levels in patients with uncontrolled type 2 diabetes: the DUAL V randomized clinical trial. JAMA. 2016;315(9):898-907.

22. Freemantle N, Mamdani M, Vilsbøll T, Kongsø JH, Kvist K, Bain SC. IDegLira versus alternative intensification strategies in patients with type 2 diabetes inadequately controlled on basal insulin therapy. Diabetes Ther. 2015;6(4):573-591.

23. Sassi F. Calculating QALYs, comparing QALY and DALY calculations. Health Policy Plan. 2006;21(5):402-408.

24. ŠUKL. Act No 363/2011. o rozsahu a podmienkach úhrady liekov, zdravotníckych pomôcok a dietetických potravín na základe verejného zdravotného poistenia a o zmene a doplnení niektorých zákonov. [Conditions of reimbursement of drugs, medical devices and dietetic food based on public health insurance]. Available from: http://www.sukl.sk/ buxus/docs//Zdravotnicke_pomocky/Formulare/zakon_363_2011_o_ rozsahu_a_podmienkach_uhrady_L__ZP_a_DP_na_zaklade_ verejneho_ZP.pdf. Slovak. Accessed October 5, 2017.

25. American Diabetes Association Consensus Panel. Guidelines for computer modeling of diabetes and its complications. Diabetes Care. 2004;27(9):2262-2265.

26. Ministry of Health of the Slovak Republic. Ministerstvo zdravotníctva Slovenskej republiky. Metodická pomôcka pre vykonávanie farmakoekonomického rozboru lieku, medicínsko-ekonomického rozboru zdravotníckej pomôcky amedicínsko-ekonomického rozboru dietetickej potraviny. [Methodic guideline for conduction of health economic analysis of a drug, medical device and dietic food]. Available from: http://www.health.gov.sk/?farmako-ekonomicky-rozbor-lieku. Slovak. Accessed October 5, 2017.

27. Hunt B, Glah D, van der Vliet M. Modeling the long-term cost-effectiveness of IDegLira in patients with type 2 diabetes who are failing to meet glycemic targets on basal insulin alone in the Netherlands. Diabetes Ther. 2017;8(4):753-765.

28. Hunt B, Mocarski M, Valentine WJ, Langer J. IDegLira versus insulin glargine U100: a long-term cost-effectiveness analysis in the US setting. Diabetes Ther. 2017;8(3):531-544.

29. McEwan P, Foos V, Palmer JL, Lamotte M, Lloyd A, Grant D. Validation of the IMS CORE Diabetes Model. Value Health. 2014;17(6):714-724.

30. Palmer AJ, Roze S, Valentine WJ, et al. The CORE Diabetes Model: projecting long-term clinical outcomes, costs and cost-effectiveness of interventions in diabetes mellitus (types 1 and 2) to support clinical and reimbursement decision-making. Curr Med Res Opin. 2004;20 Suppl 1:S5-S26.

31. World Health Organization. World Health Statistics 2012. Life Tables for WHO Member States. Geneva: World Health Organization; 2012. Available from: http://www.who.int/gho/mortality_burden_disease/ life_tables/life_tables/en/. Accessed October 5, 2017.

32. Ministry of Health of the Slovak Republic. [Regulation 422/2011]. [Vyhláška Ministerstva zdravotníctva Slovenskej republiky z 25. novembra 2011 o podrobnostiach farmako-ekonomického rozboru lieku (422/2011)]. Available from: http://www.health.gov.sk/ Clanok?lieky201511. Slovak. Accessed October 5, 2017.
33. World Health Organization. Global tobacco report. Geneva: World Health Organization. Available from: http://www.who.int/tobacco/ media/en/Slovakia.pdf. Accessed October 5, 2017.

34. World Health Organization. Global alcohol report. Geneva: World Health Organization. Available from: http://www.who.int/substance_ abuse/publications/global_alcohol_report/profiles/svk.pdf. Accessed October 5, 2017.

35. Ministry of Health of the Slovak Republic. Available from: http://www. health.gov.sk/Clanok?lieky201511. Accessed October 5, 2017.

36. Psota M, Ondrušová M, Pšenková M, Martinka E, Ilavská A. Využivanie zdravotnej starostlivosti a nákladovost' liečby diabetu a jeho komplikácií pre potreby hodnotenia nákladovej efektivnosti zdravotnickych intervencii pomocou modelu CORE na Slovensku [Health Care Resource Use and Cost of Treatment of Diabetes and Its Complications for Assessing the Cost Effectiveness of Medical Interventions using the CORE Model in Slovakia]. Bratislava: Pharm-In; 2015. Slovak.

37. Bagust A, Beale S. Modelling EuroQol health-related utility values for diabetic complications from CODE-2 data. Health Econ. 2005;14(3):217-230.

38. Clarke P, Gray A, Holman R. Estimating utility values for health states of type 2 diabetic patients using the EQ-5D (UKPDS 62). Med Decis Making. 2002;22(4):340-349.

39. Dias S, Welton NJ, Sutton AJ, Ades AE. NICE DSU technical support document 1: Introduction to evidence synthesis for decision making. 2011 [updated April 2012]. Available from: http://scharr.dept.shef. ac.uk/nicedsu/wp-content/uploads/sites/7/2016/03/TSD1-Introduction. final_.08.05.12.pdf. Accessed October 5, 2017.

40. Evans M, Khunti K, Mamdani M, et al. Health-related quality of life associated with daytime and nocturnal hypoglycaemic events: a time trade-off survey in five countries. Health Qual Life Outcomes. 2013;11:90.

41. Tengs TO, Wallace A. One thousand health-related quality-of-life estimates. Med Care. 2000;38(6):583-637.

42. Ministry of Health of the Slovak Republic. Žiadost' o zaradenie lieku do zoznamu kategorizovaných liekov a úradné určenie ceny lieku. [Request for reimbursement. Xultophy. No. 7909]. Available from: http://kategorizacia.mzsr.sk/Lieky/Common/Details/7909. Slovak. Accessed October 5, 2017.

43. Palmer AJ, Roze S, Valentine WJ, et al. Validation of the CORE Diabetes Model against epidemiological and clinical studies. Curr Med Res Opin. 2004;20 Suppl 1:S27-S40.

44. EUnetHTA. Guideline - comparators \& comparisons: direct and indirect comparisons. 2013. Available from: http://eunethta.eu/sites/ default/files/sites/5026.fedimbo.belgium.be/files/Comparators $\% 20$ $\% 26 \% 20$ Comparisons $\% 20 \% 20$ Direct $\% 20$ and $\% 20$ indirect $\% 20$ comparisons_Amended\%20JA1\%20Guideline_Final\%20Nov\%202015. pdf. Accessed October 5, 2017.

45. Zinman B, Schmidt WE, Moses A, Lund N, Gough S. Achieving a clinically relevant composite outcome of an $\mathrm{HbA} 1 \mathrm{c}$ of $<7 \%$ without weight gain or hypoglycaemia in type 2 diabetes: a meta-analysis of the liraglutide clinical trial programme. Diabetes Obes Metab. 2012;14(1):77-82.

46. Vora J, Christensen T, Rana A, Bain SC. Insulin degludec versus insulin glargine in type 1 and type 2 diabetes mellitus: a meta-analysis of endpoints in phase 3a trials. Diabetes Ther. 2014;5(2):435-446.

47. Aroda V, Jaeckel E, Jarlov H, Abrahamsen T, Vilsbøll T. Incidence of gastrointestinal side effects similar between IDegLira and non-GLP-1 RA comparators. Poster presented at: ADA 2015; June 5-9, 2015; Boston, MA. 


\section{Supplementary materials}

Table SI Baseline cohort characteristics

\begin{tabular}{|c|c|}
\hline Characteristics & DUAL II ${ }^{\ddagger}$ cohort (patients receiving IDegLira) \\
\hline \multicolumn{2}{|l|}{ Demographics and risk factors, mean (SD) } \\
\hline Start age (years) & $56.8(8.9)$ \\
\hline Duration of diabetes (years) & $10.3(6.0)$ \\
\hline Percentage male $(\%)$ & 56.3 \\
\hline $\mathrm{HbA}_{\mathrm{Ic}}(\%)$ & $8.7(0.7)$ \\
\hline $\mathrm{SBP}(\mathrm{mmHg})$ & I32.4 (|4.8) \\
\hline Total cholesterol (mg/dL) & $182.0(45.5)$ \\
\hline HDL cholesterol (mg/dL) & $43.4(11.0)$ \\
\hline LDL cholesterol (mg/dL) & $101.9(37.1)$ \\
\hline Triglycerides (mg/dL) & $196.8(148.0)$ \\
\hline $\mathrm{BMI}\left(\mathrm{kg} / \mathrm{m}^{2}\right)$ & $33.6(5.7)$ \\
\hline Percentage smokers (\%) & 16.1 \\
\hline Cigarettes per day (as per reference I) & 12.7 \\
\hline Alcohol consumption (fl oz/week) (as per reference 2) & 4.66 \\
\hline \multicolumn{2}{|l|}{ Baseline cardiovascular complications, $\%$} \\
\hline History of myocardial infarction & 6.0 \\
\hline History of angina & 6.5 \\
\hline History of peripheral vascular disease & 0.5 \\
\hline History of stroke & 1.0 \\
\hline History of congestive heart failure & 5.0 \\
\hline History of atrial fibrillation & 1.5 \\
\hline History of left ventricular hypertrophy & 0.5 \\
\hline \multicolumn{2}{|l|}{ Baseline renal complications, $\%$} \\
\hline History of microalbuminuria & 0.5 \\
\hline History of gross proteinuria & 2.5 \\
\hline History of end-stage renal disease & 1.5 \\
\hline \multicolumn{2}{|l|}{ Baseline retinopathy complications, $\%$} \\
\hline History of background diabetic retinopathy & 0.0 \\
\hline History of proliferative diabetic retinopathy & 0.5 \\
\hline History of severe vision loss & 0.0 \\
\hline History of macular edema & 0.0 \\
\hline History of cataract & 4.0 \\
\hline \multicolumn{2}{|l|}{ Baseline neuropathy, ulcer, and amputation, \% } \\
\hline History of neuropathy & 9.5 \\
\hline History of amputation & 0.0 \\
\hline
\end{tabular}

Notes: I fl oz is equal to $29.57 \mathrm{~mL}$. *DUAL II is a randomized, controlled, double-blind, multinational, treat-to-target trial in which IDegLira was compared with IDeg over 26 weeks of treatment in patients with T2DM uncontrolled on basal insulin. ${ }^{3}$ Reproduced from Hunt B, Glah D, van der Vliet M. Modeling the Long-Term Cost-Effectiveness of IDegLira in Patients with Type 2 Diabetes Who are Failing To Meet Glycemic Targets on Basal Insulin Alone in The Netherlands. Diabetes Ther. 2017;8(4):753-765. ${ }^{5}$

Abbreviations: BMI, body mass index; $\mathrm{HbA}_{\mathrm{Ic}}$, glycated hemoglobin $\mathrm{A}_{\mathrm{Ic}} ; \mathrm{HDL}$, high-density lipoprotein; IDeg, insulin degludec; IDegLira; insulin degludec/liraglutide; LDL, low-density lipoprotein, SBP, systolic blood pressure; SD, standard deviation; T2DM, type 2 diabetes mellitus.

Table S2 Patient management resource use

\begin{tabular}{ll}
\hline Patient management & Percentage of patients receiving management (\%) \\
\hline Primary prevention aspirin & 22.5 \\
Secondary prevention aspirin & 92.5 \\
Primary prevention statins & 45.0 \\
Secondary prevention statins & 77.5 \\
Primary prevention ACE inhibitors & 42.5 \\
Secondary prevention ACE inhibitors & 72.5 \\
Foot ulcer prevention program & 83.3 \\
Screening for eye disease & 90.0 \\
Screening for renal disease & 99.0 \\
Intensive insulin treatment after myocardial infarction & $65.0 *$ \\
\hline
\end{tabular}

Notes: *Assumed part of standard care. Reproduced from Hunt B, Glah D, van der Vliet M. Modeling the Long-Term Cost-Effectiveness of IDegLira in Patients with Type 2 Diabetes Who are Failing To Meet Glycemic Targets on Basal Insulin Alone in The Netherlands. Diabetes Ther. 2017;8(4):753-765. ${ }^{5}$

Abbreviations: ACE, angiotensin-converting enzyme; IDegLira; insulin degludec/liraglutide. 
Table S3 Annual per-patient management costs

\begin{tabular}{ll}
\hline Patient management & Annual cost (EUR) \\
\hline Aspirin & 13.39 (IMS Medical Index MAT I2/20I4., Data on file, 20I4) \\
Statins & 13.01 (IMS Medical Index MAT I2/20I4., Data on file, 20I4) \\
ACE inhibitors & 31.12 (IMS Medical Index MAT I2/20I4., Data on file, 20I4) \\
Microalbuminuria screening & $9.03^{4}$ \\
Gross proteinuria screening & $9.97^{4}$ \\
Stopping ACE inhibitors due to adverse events & $8.26^{4}$ \\
Screening for eye disease & $26.41^{4}$ \\
Screening for diabetic foot complications & $16.27^{4}$ \\
\hline
\end{tabular}

Note: EUR, 2015 Euros.

Abbreviation: ACE, angiotensin-converting enzyme.

Table S4 Cost of treating diabetes-related complications

\section{Complication}

Myocardial infarction, year of event

Myocardial infarction, years 2+

Angina, year of onset

Angina, years 2+

Congestive heart failure, year of onset

Congestive heart failure, years $2+$

Stroke, year of event

Stroke, death within 30 days

Peripheral vascular disease, onset

Peripheral vascular disease, years $2+$

Hemodialysis, onset

Hemodialysis, years 2+

Peritoneal dialysis, onset

Peritoneal dialysis, years $2+$

Kidney transplant, first year

Kidney transplant, years 2+

Non-severe hypoglycemia

Severe hypoglycemia

Laser treatment

Cataract operation

Blindness, first year

Blindness, years 2+

Neuropathy, year of onset

Neuropathy, years 2+

Amputation, procedure

Amputation, prosthesis

Gangrene treatment

Infected foot ulcer

Uninfected foot ulcer
Stroke, years $2+$

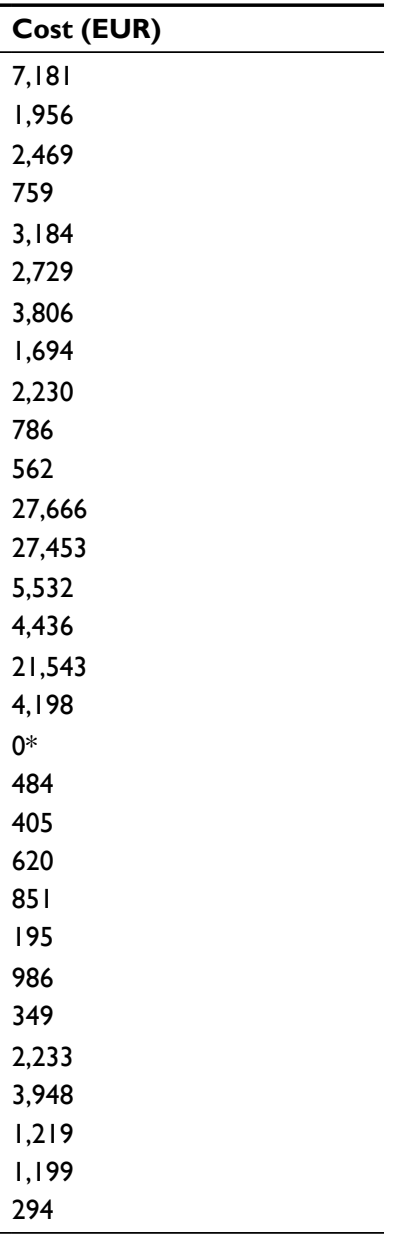

Notes: Costs were derived from the study by Psota et al. ${ }^{4}$ *Assumed. EUR, 2015 Euros.

Table S5 Sensitivity analysis results

\begin{tabular}{llll}
\hline & \multicolumn{3}{l}{ IDegLira vs basal-bolus therapy } \\
\cline { 2 - 4 } & $\Delta$ cost (EUR) & $\Delta$ QALY & ICER (EUR) \\
\hline Base case & $+2,449$ & +0.29 & 8,590 \\
Time horizon $+30 \%$ & $+2,449$ & +0.29 & 8,590 \\
Time horizon $-30 \%$ & $+2,382$ & +0.29 & 8,115 \\
Discount rate $+30 \%$ & $+2,354$ & +0.26 & 9,049 \\
Discount rate $-30 \%$ & $+2,554$ & +0.32 & 8,075 \\
HbA $_{\mathrm{Ic}}$ difference $+30 \%$ & $+2,423$ & +0.30 & 8,034 \\
$\mathrm{HbA}_{\mathrm{Ic}}$ difference $-30 \%$ & $+2,477$ & +0.28 & 9,022 \\
\hline
\end{tabular}


Table S5 (Continued)

\begin{tabular}{|c|c|c|c|}
\hline & \multicolumn{3}{|c|}{ IDegLira vs basal-bolus therapy } \\
\hline & $\Delta$ cost (EUR) & $\triangle$ QALY & ICER (EUR) \\
\hline Blood pressure difference $+30 \%$ & $+2,489$ & +0.29 & 8,479 \\
\hline Blood pressure difference $-30 \%$ & $+2,473$ & +0.28 & 8,905 \\
\hline Lipid difference $+30 \%$ & $+2,438$ & +0.30 & 8,224 \\
\hline Lipid difference $+30 \%$ & $+2,446$ & +0.28 & 8,847 \\
\hline BMI difference $+30 \%$ & $+2,452$ & +0.31 & 7,959 \\
\hline BMI difference $-30 \%$ & $+2,489$ & +0.26 & 9,603 \\
\hline Hypoglycemia difference $+30 \%$ & $+2,416$ & +0.32 & 7,494 \\
\hline Hypoglycemia difference $-30 \%$ & $+2,493$ & +0.26 & 9,755 \\
\hline Treatment switching at 3 years in IDegLira arm & $+1,526$ & +0.21 & 7,413 \\
\hline Treatment switching at 7 years in IDegLira arm & $+3,244$ & +0.36 & 9,100 \\
\hline No switching & $+6,724$ & +0.65 & 10,384 \\
\hline Cost of complications $+30 \%$ & $+2,331$ & +0.29 & 8,178 \\
\hline Cost of complications $-30 \%$ & $+2,567$ & +0.29 & 9,002 \\
\hline Disutilities associated with hypoglycemic events $+30 \%$ & $+2,449$ & +0.32 & 7,629 \\
\hline Disutilities associated with hypoglycemic events $-30 \%$ & $+2,449$ & +0.25 & 9,823 \\
\hline Updated IMS CORE Diabetes Model & $+2,565$ & +0.27 & 9,486 \\
\hline Pooled analysis with narrow basal-bolus arm & $+2,870$ & +0.33 & 8,715 \\
\hline
\end{tabular}

Note: EUR, 2015 Euros.

Abbreviations: BMI, body mass index; $\mathrm{HbA}_{\mathrm{Ic}}$, glycated haemoglobin AIc; ICER, incremental cost-effectiveness ratio; IDegLira; insulin degludec/liraglutide; QALY, qualityadjusted life years.

\section{References}

1. World Health Organization. Global tobacco report. Geneva: World Health Organization. Available from: http://www.who.int/tobacco/media/en/ Slovakia.pdf. Accessed October 5, 2017.

2. World Health Organization. Global alcohol report. Geneva: World Health Organization. Available from: http://www.who.int/substance_abuse/publications/global_alcohol_report/profiles/svk.pdf. Accessed October 5, 2017.

3. Buse JB, Vilsbøll T, Thurman J, et al; NN9068-3912 (DUAL-II) Trial Investigators. Contribution of liraglutide in the fixed-ratio combination of insulin degludec and liraglutide (IDegLira). Diabetes Care. 2014;37(11):2926-2933.
4. Psota M, Ondrušová M, Pšenková M, Martinka E, Ilavská A. Využivanie zdravotnej starostlivosti a nákladovost' liečby diabetu a jeho komplikácií pre potreby hodnotenia nákladovej efektivnosti zdravotnickych intervencií pomocou modelu CORE na Slovensku [Health Care Resource Use and Cost of Treatment of Diabetes and Its Complications for Assessing the Cost Effectiveness of Medical Interventions using the CORE Model in Slovakia]. Bratislava: Pharm-In; 2015. Slovak.

5. Hunt B, Glah D, van der Vliet M. Modeling the Long-Term Cost-Effectiveness of IDegLira in Patients with Type 2 Diabetes Who are Failing To Meet Glycemic Targets on Basal Insulin Alone in The Netherlands. Diabetes Ther. 2017;8(4):753-765.
ClinicoEconomics and Outcomes Research

\section{Publish your work in this journal}

ClinicoEconomics and Outcomes Research is an international, peerreviewed open-access journal focusing on health technology assessment, pharmacoeconomics and outcomes research in the areas of diagnosis, medical devices, and clinical, surgical and pharmacological intervention. The economic impact of health policy and health systems organization also constitute important areas of coverage. The manuscript management system is completely online and includes a very quick and fair peer-review system, which is all easy to use. Visit http://www.dovepress.com/testimonials.php to read real quotes from published authors. 